\title{
Pengaruh Pemberian Kompos Enceng Gondok (Eichornia crassipes Solm) Terhadap laju Pertumbuhan Tanaman Cabai (Capsicum frutescens L.)
}

\author{
Ningsih Rahmawati ${ }^{1}$, Muh. Nasir ${ }^{2}$ dan Ariyansyah ${ }^{3}$ \\ ${ }^{1}$ Mahasiswa Program Studi Pendidikan Biologi, STKIP Bima. Jalan Piere Tendean Kel. Mande Tel. \\ Fax (0374) 42801, Bima 84191, Indonesia. \\ 23 Dosen Program Studi Pendidikan Biologi, STKIP Bima. Jalan Piere Tendean Kel. Mande Tel. Fax \\ (0374) 42801, Bima 84191, Indonesia. \\ Email: ningsirahmawati3497@yahoo.com
}

\begin{abstract}
Abstrak: Penelitian ini bertujuan untuk mengetahui pengaruh Pemberian Kompos Eceng Gondok (Eichornia crassipes Solm) Terhadap Pertumbuhan Cabai (Capsicum frutescens L). Desain menggunakan Rangangan Acak Kelompok (RAK). Populasi dalam penelitian ini adalah biji tanaman cabai (Capsicum frutescens $L$ ) yang tersedian sebanyak 1 bungkus sedangkan yang menjadi sampelnya adalah 36 biji cabai (Capsicum frutescens L). Parameter pengamatan dalam penelitian ini adalah tinggi tanaman dan jumlah daun. Pengumpulan data dalam penelitian ini dilakukan dengan pengamatan langsung terhadap parameter di lapangan yaitu tinggi tanaman dan jumlah daun. Data dianalisis dengan ANOVA (analysis of variance). Hasil analisis data menunjukan bahwa pertumbuhan cabai (Capsicum frutescens L) pada perlakuan ketiga (P3) dengan menggunakan kompos eceng gondok (Eichornia crassipes solm) $1 \mathrm{~kg}$ berbanding $2 \mathrm{~kg}$ tanah yang memberikan pengaruh terbaik, hal ini terlihat pada tinggi tanaman umur 15 HST dengan rata-rata 7,46 menghasilkan F-Hitung > F-tabel $(5,1722>4,76)$ sedangkan pada umur 30 HST dengan rata-rata 19,33 menghasilkan F-Hitung > F-Tabel (6,844 > 4,76) sehingga dilanjutkan (BNT) uji Beda Nyata Terkecil taraf signifikan 5\%. Berdasarkan hasil analisis data jumlah daun tanaman cabai (Capsicum frutescens L) menunjukan hasil yang tidak signifikan pada umur 15 HST dengan rata-rata yaitu F-Hitung < F-Tabel $(0,666<4,76)$ sehingga tidak dilanjutkan uji (BNT) uji Beda Nyata Terkecil taraf signifikan 5\%, Sedangkan pada umur 30 HST menunjukan hasil yang signifikan dengan rata-rata 12 dan menghasilkan F-Hitung > FTabel (41,665 > 4,76) sehingga dilanjutkan uji (BNT) uji Beda Nyata Terkecil taraf signifikan $5 \%$.
\end{abstract}

Kata Kunci: Kompos eceng gondok, Eichornia crassipes Solm, pertumbuhan cabai, Capsicum frutscens $\mathrm{L}$

\section{PENDAHULUAN}

Eceng gondok (Eichornia crassipes solm.) merupakan tanaman gulma di wilayah perairan yang hidup terapung pada air yang dalam. Perkembangbiakan dengan cara vegetatif dalam waktu 7-10 hari dapat mencapai jumlah dua kali lebih banyak. Satu batang eceng gondok (Eichornia crassipes solm) dalam waktu 52 hari mampu berkembang seluas $1 \mathrm{~m}^{2}$, atau dalam waktu 1 tahun mampu menutup area seluas $7 \mathrm{~m}^{2}$ (Juliani, R. et al 2017). Sedangkan Heyne K. (1987) menyatakan bahwa dalam waktu 6 bulan pertumbuhan eceng gondok pada areal 1 ha dapat mencapai bobot basah sebesar 125 ton.

Eceng gondok (Eichornia crassipes solm) merupakan salah satu tumbuhan 
pengganggu atau biasa disebut gulma yang merusak lingkungan perairan karena tumbuhan ini mempunyai daya adaptasi yang sangat besar pada lingkungan baru dan berkembang biak dengan sangat cepat.

Masalah eceng gondok (Eichornia crassipes solm) dapat ditanggulangi dengan cara mengambilnya tanpa menimbulkan masalah baru, oleh karna itu eceng gondok (Eichornia crassipes solm) yang telah diambil itu sebaiknya dimanfaatkan dan salah satunya dengan menjadikannya sebagai kompos.

Penggunaan pupuk hijau, pupuk hayati, kompos dan ektrak daun diharapkan mampu memperbaiki kondisi tanah yang rusak dan dapat meningkatkan produktivitas tanaman (Susanto, 2002, dalam Hidayatullah, 2017).

Menurut (Kristanto, 2003; Oktaviana dan Tengku, 2016) bahwa kandungan bahan organik dalam $100 \%$ berat basah dari kompos eceng gondok (Eichornia crassipes Solm) seperti C organik 21,23\%, $\mathrm{N}$ total 0,28 \%, P total $0,001 \%$, dan $\mathrm{K}$ total $0,016 \%$, berdasarkan kandungan ini peneliti bertujuan untuk menggunakan kompos eceng gondok (Eichornia crassipes solm) sebagai kompos untuk tanaman cabai (Capsicum frutescens L). Hal ini mengingat karena tanaman cabai (Capsicum frutescens L) merupakan salah satu komoditas hortikultura yang bernilai ekonomi tinggi.
Adapun tujuan dari penelitian ini adalah untuk mengetahui pengaruh pemberian kompos eceng gondok (Eichornia crassipes solm) terhadap pertumbuhan cabai (Capsicum frutescens $\mathrm{L}$ ).

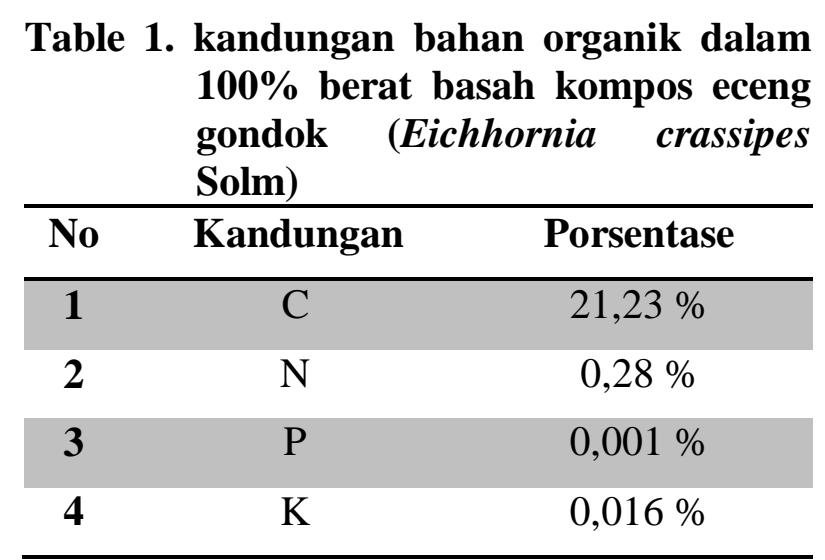

Sumber: (Kristanto, 2003 dalam oktaviana dan tengku, 2016).

\section{METODE}

Jenis penelitian ini adalah penelitian eksperimen terapan, mencari pengaruh pemberian kompos eceng gondok (Eichornia crasipes Solm) sebagai variabel bebas terhadap pertumbuhan cabai (Capsicum frutescens L) sebagai variabel terikat. Desain penelitian yang digunakan dalam penelitian ini adalah Rancangan Acak Kelompok (RAK) yang terdiri dari 4 (empat) perlakuan dan masing-masing pengulangan sebanyak 3 (tiga) kali sehingga total percobaan yang dilakukan sebanyak 12 (dua belas) unit percobaan yang di tanami dengan masing-masing 3 pohon cabai (Capsicum frutescens L). Penelitian dilaksanakan selama dua bulan 
Pembuatan Kompos menggunakan eceng gondok yang dipotong kecil-kecil, EM4, gula pasir, dan air. Pada hari ke 8 - 12 kompos telah matang, apabila dibuka nampak ditumbuhi jamur berwarna putih dan apabila dipegang terasa hangat. Kompos ini sudah bisa digunakan.

Parameter yang diiukur Tinggi Tanaman (cm), Jumlah Daun (helai) pengukuran ini dilakukan pada hari ke 15 HST dan 30 HST. Uji hipotesis yang diajukan dilakukan dengan menggunakan ANOVA (Analisis Of Variance). Melalui analisis nyata atau tidak, nilai tersebut dibandingkan dengan F-tabel, maka hasil uji signifikan, ini berarti antara perlakuan pada tanaman percobaan secara umum terdapat perbedaan yang nyata, maka dilanjutkan dengan uji BNT (Beda Nyata Terkecil) pada taraf signifikan 5\%.

\section{HASIL DAN PEMBAHASAN}

Setelah tanaman cabai (Capsicum frutescens $\mathrm{L}$ ) tumbuh dan berkembang maka dilakukan pengamatan di lapangan yaitu dengan mengukur tinggi tanaman $(\mathrm{cm})$ dan jumlah daun (helai) pada umur 15 dan 30 HST (Gambar 1).

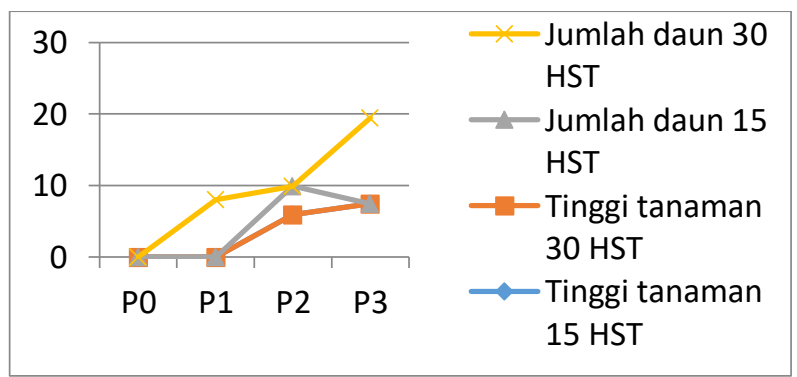

Gambar 1. Grafik parameter pertumbuhan Tanaman Cabai

23 Oryza Jurnal Pendidikan Biologi

\section{Tinggi tanaman}

Berdasarkan hasil analisis data menunjukan bahwa pertumbuhan tinggi tanaman cabai (Capsicum frutescens L) pada perlakuan ketiga (P3) dengan menggunakan kompos eceng gondok (Eichornia crassipes solm) $1 \mathrm{~kg}$ berbanding $2 \mathrm{~kg}$ tanah yang paling tinggi pengaruhnya, pada umur 15 HST dengan rata-rata 7,46 menghasilkan F-Hitung $>$ F-tabel $(5,1722>4,76)$ sedangkan pada umur 30 HST dengan rata-rata 19,33 menghasilkan F-Hitung > F-Tabel (6,844> 4,76) sehingga dilanjutkan (BNT) uji Beda Nyata Terkecil taraf signifikan 5\%.

Tabel 1. Analisis keragaman Tinggui tanaman cabai (Capsicum frutescens L) pada umur 30 hari setelah tanam.

\begin{tabular}{|c|c|c|c|c|c|}
\hline SK & $\mathrm{dlb}$ & $\mathrm{JK}$ & $\mathrm{KT}$ & Fh & $\mathrm{Ft}$ \\
\hline Perlakuan & 3 & $\begin{array}{l}\mathrm{JKP}= \\
185,673\end{array}$ & $\begin{array}{l}\text { KTP = } \\
61,891\end{array}$ & 6,84 & 4,76 \\
\hline Kelompok & 2 & $\begin{array}{l}\mathrm{JKK}= \\
713,649\end{array}$ & $\begin{array}{l}\text { KTK = } \\
356,824\end{array}$ & & \\
\hline Galat & 6 & $\begin{array}{l}\mathrm{JKG}= \\
3,007\end{array}$ & $\begin{array}{l}\text { KTG }= \\
9,042\end{array}$ & & \\
\hline Total & 11 & $\begin{array}{l}\mathrm{JKT}= \\
2,108\end{array}=$ & & & \\
\hline
\end{tabular}

Keterangan: *)berbeda nyata pada taraf signifikan $5 \%$

\section{Jumlah daun}

Berdasarkan hasil analisis data keragaman jumlah daun tanaman cabai (Capsicum frutescens L) pada perlakuan ketiga (P3) dengan menggunakan kompos eceng gondok (Eichornia crassipes solm) $1 \mathrm{~kg}$ berbanding $2 \mathrm{~kg}$ tanah yang paling tinggi pengaruhnya dan menunjukan hasil yang tidak 
signifikan pada umur 15 HST dengan rata-rata yaitu F-Hitung $<$ F-Tabel $(0,666<4,76)$ sehingga tidak dilanjutkan uji (BNT) uji Beda Nyata Terkecil taraf signifikan 5\%, hal ini senada dengan penelitian yang dilakukan oleh Yanuarismah (2012) tentang pengaruh kompos eceng gondok (Eichornia crassipes solm) terhadap pertumbuhan dan produksi selada (Lactuca sativa L) Konsentrasi kompos enceng gondok (Eichornia crassipes solm) berpengaruh nyata terhadap tinggi tanaman, berat akar tanaman, dan berat segar selada, tetapi tidak berpengaruh terhadap jumlah daun.

Sedangkan pada umur 30 HST menunjukan hasil yang signifikan dengan rata-rata 12 dan menghasilkan F-Hitung > F-Tabel (41,665 > 4,76) sehingga dilanjutkan uji (BNT) uji Beda Nyata Terkecil taraf signifikan 5\%.

Tabel 2. Analisis keragaman jumlah helai daun tanaman cabai (Capsicum frutescens L) pada umur 30 hari setelah tanam.

\begin{tabular}{|c|c|c|c|c|c|c|}
\hline SK & dlb & JK & & $\mathrm{KT}$ & Fh & $\mathrm{Fit}$ \\
\hline Perlakuan & 3 & $\begin{array}{l}\text { JKP } \\
52\end{array}$ & $=$ & $\begin{array}{l}\mathrm{KTP}= \\
17,333\end{array}$ & $\begin{array}{l}41,6 \\
6\end{array}$ & 4,76 \\
\hline Kelompok & 2 & $\begin{array}{l}\text { JKK } \\
3,5\end{array}$ & $=$ & $\begin{array}{l}\mathrm{KTK}= \\
1,75\end{array}$ & & \\
\hline Galat & 6 & $\begin{array}{l}\text { JKG } \\
2,5\end{array}$ & $=$ & $\begin{array}{l}\text { KTG = } \\
0,416\end{array}$ & & \\
\hline Total & 11 & $\begin{array}{l}\text { JKT } \\
58\end{array}$ & $=$ & & & \\
\hline
\end{tabular}

Keterangan: *)berbeda nyata pada taraf signifikan $5 \%$

Secara parsial/khusus didapatkan bahwa kompos eceng gondok (Eichornia crassipes Solm) berpengaruh terhadap tinggi tanaman cabai (Capsicum frutescens $\mathrm{L}$ ) baik pada umur 15 maupun pada umur 30 HST dengan hasil yang signifikan. Sementara untuk jumlah daun tanaman cabai (Capsicum frutescens L) pada umur 15 HST tidak signifikan sedangkan pada umur 30 HST menunjukan hasil yang signifikan. Sehingga dapat disimpulkan secara simultan/umum bahwa kompos eceng gondok (Eichornia crassipes Solm) dapat mempengaruhi tinggi tanaman dan jumlah daun.

Hasil penelitian ini ternyata menerima hipotesis penelitian yang diajukan,yaitu ada pengaruh pemberian kompos eceng gondok (Eichornia crasipes Solm) terhadap pertumbuhan tanaman cabai (Capsicum frutescens $\mathrm{L}$ ).

\section{KESIMPULAN}

Berdasarkan hasil analisis data menunjukan bahwa pertumbuhan tinggi tanaman cabai (Capsicum frutescens L) pada perlakuan ketiga (P3) dengan menggunakan kompos eceng gondok (Eichornia crassipes solm) $1 \mathrm{~kg}$ berbanding $2 \mathrm{~kg}$ tanah yang paling tinggi pengaruhnya, pada umur 15 HST dengan rata-rata 7,46 menghasilkan F-Hitung $>$ F-tabel $(5,1722>4,76)$ sedangkan pada umur 30 HST dengan rata-rata 19,33 menghasilkan F-Hitung > F-Tabel (6,844> 4,76) sehingga dilanjutkan (BNT) uji Beda Nyata Terkecil taraf signifikan 5\%. Sedangkan 
hasil analisis data keragaman jumlah daun tanaman cabai (Capsicum frutescens L) menunjukan hasil yang tidak signifikan pada umur 15 HST dengan rata-rata yaitu F-Hitung $<$ F-Tabel $(0,666<4,76)$ sehingga tidak dilanjutkan uji (BNT) uji Beda Nyata Terkecil taraf signifikan 5\%, Sedangkan pada umur 30 HST menunjukan hasil yang signifikan dengan rata-rata 12 dan menghasilkan F-Hitung > FTabel (41,665 > 4,76) sehingga dilanjutkan uji (BNT) uji Beda Nyata Terkecil taraf signifikan $5 \%$.

\section{DAFTAR PUSTAKA}

Juliani, R, et all. (2017). Pupuk Organik Enceng Gondok Dari Danau Toba, Jurnal Pengabdian Kepada Masyarakat: Volume 23 No. 1, januari-maret 2017.

Heyne, K. (1987). Tumbuhan Berguna Indonesia Jilid II. Badan Penelitian dan Pengembangan Kehutanan. Departemen Kehutanan. Bogor.

Hidayatullah, S. (2017). pengaruh pemberian pupuk organik dari daun gamal (Gliricidia sepium) terhadap pertumbuhan Bayam (Amaranthus hybridus L.). Skripsi: Program Studi Pendidikan Biologi STKIP BIMA.

Yanuarismah. Y. (2012). Pengaruh Kompos Eceng Gondok (Eichornia crassipes solm) Terhadap Pertumbuhan Dan Produksi Selada (Lactuca sativa L). Naskah Publikasi: Fakultas Keguruan Dan Ilmu Pendidikan Universitas Muhammadiyah Surakarta. 